\title{
Effect of Transformational Leadership on Employees' Innovativeness and Job Satisfaction in Pakistani Private Sector
}

\author{
Mohammad Irfan ${ }^{1}$ \\ Fayiza Manzoor Ahmed ${ }^{2 *}$ \\ Management and Science University (MSU), Malaysia ${ }^{1}$ \\ Universiti Kebangsaan Malaysia (UKM), Malaysia ${ }^{2}$
}

\begin{abstract}
According to leadership literature, current transformational leadership styles are associated with job satisfaction to varying degrees. According to several studies, transformational leadership leads to higher levels of job satisfaction. Given the current state of the Pakistani business market, the study's overarching goal was to investigate the relationship between transformational leadership styles and employees' levels of innovativeness and job satisfaction in the Pakistani private sector. To achieve the study's objectives, a quantitative study was conducted. Questionnaires were distributed to employees in Pakistan's private sector from a predetermined target population. The data collected was analysed using statistical software. According to the study's findings, there are statistically significant relationships between overall transactional leadership, employee innovativeness, and job satisfaction, as well as overall transformational leadership and job satisfaction. This study is one of the few that focuses on the private sector to help improve understanding of how to manage and retain employees in the private sector. These findings are also useful for the Asia-Pacific private sector in maintaining the work-life balance of affective commitments, which leads to positive inrole performance.
\end{abstract}

Keywords: Leadership, Leadership styles, Job satisfaction, employees, Private sector

*Corresponding author: Fayiza Manzoor Ahmed; Email: fayiza_mzr@yahoo.com DOI: https://doi.org/10.37227/jibm-2021-09-1497

\section{Introduction}

Organizations face increased global competition and the challenge of maintaining a competitive advantage in a complex business world (Al-Awlaqi, Battour, Barahma \& Aamer, 2021). Organizations in the twenty-first century must seek alternative methods of operation in order to be more effective, efficient, and creative (Bahadori, Hosseini, Alimohammadzadeh, Hasanpoor \& Ghasemi, 2021). Leaders must be aware of cultural differences that may influence business practises in other countries in order to succeed in international business (Zhang \& Kang, 2020). To ensure the success of virtual teams in the twenty-first century, leaders must be acutely aware of global virtual teams (GVTs) (Wilson, 2020). According to one study (Wang, Morrison, Xie, Zhang \& Coca-Stefaniak, 2020), leadership is a process in which one influences the behaviour of another through personality 
and intellect rather than through violence or threat. Leaders are one-of-a-kind, and different leadership styles can have a different impact on transformation, with some leaders being more effective than others (Scicluna \& Sammut, 2020).

In today's fast-paced advancement of technological innovation in dynamic markets, it is critical for organisations to stay current on new developments in order to gain a competitive advantage (Quartey, Dartey-Baah \& Adotey, 2020). Through the innovativeness and efficient productivity of their employees, organisations would be able to find a position at the forefront of knowledge, or even become the leading producers of knowledge and innovation (Muhammed \& Zaim, 2020). To some extent, research has found statistical correlations between leadership styles and employee job satisfaction levels (Amah \& Oyetuunde, 2020). A study (Ghiasipour, Mosadeghrad, Shaqura \& Jaafaripooyan, 2020) found that employees managed with a transformational leadership style had higher levels of job satisfaction when compared to associated factors such as charisma and intellectual stimulation. Employees managed under a transactional leadership style, on the other hand, reported higher levels of job dissatisfaction when compared to associated factors such as management by exception (Luo, Guo, \& Cheng, 2020). As a result, in the current climate, the role of a leader is critical to organisational success. Transformational leadership, transactional leadership, and laissez-faire leadership are identified as the three most common leadership styles in the current climate by leadership literature, with transformational leadership and transactional leadership being the most dominant (Ali, Imran, Almansoori, Zeb \& Rehman, 2020).

Employees are viewed as intangible assets that contribute to an organization's longterm success and development (Liang et al., 2020). According to the findings of a study (Kanthong, Khummueng \& Na-Nan, 2020), good working conditions increased employee job satisfaction. Employee moods and emotions are fundamental building blocks that comprise the affective component of job satisfaction (Abdullahi, Anyigba \& Anarfo, 2020). Employees who are satisfied with their jobs are more committed to their jobs and organisations (Al-Ghazali, 2020). Leadership, virtual teams, and employee job satisfaction are all topics covered in numerous studies, books, and articles (Hsu, Hsieh, Wang, \& Kao, 2020). Many of these publications investigated the effects of leadership and electronicmediated communications, but they focused on a specific aspect, such as motivation or job satisfaction (Chen, Zhang, Yang, Chang \& Zhou, 2020). More research is needed to better understand the nature of the relationships that exist between employee job satisfaction and perceived leadership effectiveness in virtual team environments (Asad \& Nawab, 2020). Furthermore, other predictor variables that predict employee job satisfaction and leadership effectiveness, such as diversity and team longevity, should be investigated (Anadol \& Behery, 2020).

Employee job satisfaction affects every industry and can be the deciding factor in deciding whether to stay or leave (Portela Maquieira, Tar \& Molina-Azorn, 2020). However, studies on transformational leadership constructs and employee job satisfaction in federal government sectors have lacked an understanding of how leaders and employees collaborate to determine what constitutes job satisfaction (Singh, Srivastava, \& Singh, 2020). Although transformational leadership has many different types of positive effects at the organisational, team, and individual levels, subordinates' leadership preferences vary depending on their personalities or characteristics (Khan et al., 2017; Strömberg \& Vidman, 2020). It has been proposed that inventiveness be treated as an independent variable (Vandavasi, Yepuru, Uen $\&$ McConville, 2020). Furthermore, it has been suggested that transformational leaders' subdimensions receive more attention because different antecedents may correlate with different 
aspects of leadership behaviours (Sarwar, Zahid, Imran \& Anjum, 2020). There have been no studies on how the most creative and innovative people perceive them as having varying levels of importance (Vandavasi et al., 2020).

Taking these viewpoints into account, this study investigated this issue by analysing the experiences of those who worked in the private sector in Pakistan. The economies of Asia's rentier states have long been declared unsustainable in the long run (Alenezi, 2020). Multiple recommendations from various international organisations and consultancies have been consistently issued stating the need for Asia's countries to diversify their sources of income and reduce the growing budget spending, which has become a serious economic burden expected to result in budget deficit and fiscal crisis in the not-too-distant future even in the wealthiest of those states (Sorour, El-Sakhawy, Soobaroyen \& Shrives, 2020). In terms of such economic diversification efforts, Pakistan is an intriguing case study. Pakistan has lagged far behind its Asian peers in terms of non-oil sector development. The need for concrete policy steps was recently emphasised by a new IMF report revealing the bleak prospect of the country facing a real budget deficit as early as 2017. (Mohamed, 2019). Despite the importance of the private sector in today's business world, research to date has lacked specificity in addressing effective leadership styles in the private sector (Wallo, Ellström, Elg, Kock \& Berglund, 2020). Thus, the goal of this study was to determine how transformational leadership affects employee satisfaction and creativity, as well as whether it increases productivity in private sector employees in Pakistan.

\section{Job Satisfaction}

\section{Literature Review}

It is the amount of positive overall feelings that people have about their jobs (Vandavasi et al., 2020). People form attitudes toward their jobs by taking into account their feelings, behaviours, and beliefs (Strömberg \& Vidman, 2020). According to the literature, theories of motivation are used to address job satisfaction (Almeida Jones, Knight, Mitchell, \& Harvey, 2021). Employee motivation is a major factor in the success of any organisation (Portela Maquieira et al., 2020). Employees who are motivated are more committed to their jobs and organisations (Taufer, Severo, Perin \& De Guimares, 2020). A motivated workforce would result in increased efficiency and lower turnover, which would have a positive impact on the organization's overall success (Neve, Kseler, Wandahl \& Jensen, 2019). As a result, it is a constant challenge for organisations to create a motivating environment for employees to work in in order to achieve organisational success (Le \& Nguyen, 2019). As a result, one can only be motivated if they are satisfied with the current job content. Simply put, before being motivated to excel to higher levels, one must first be satisfied with the job content. A study (Kundu, Kumar \& Lata, 2019) found that motivation stems from a person's desire to achieve personal goals. It also states that a person's behaviour is directly influenced by a set of needs. Need theories, Equity theories, and Job Characteristics theories are among the motivational theories that address job satisfaction, according to (Mascarenhas, 2019b). According to Herzberg, the only way to increase satisfaction is through a challenging job (Skelton, Dwyer \& Nattress, 2019). In order to achieve job satisfaction, jobs should include intrinsically rewarding motivators. According to the equity theory, job satisfaction is not solely determined by a person's belief that reward outweighs effort. Rather, job satisfaction is determined by comparing an employee's rewards to those of others in a comparable position (Ohiani \& Adeosun, 2020). 


\section{Transformational Leadership}

Leadership entails influencing colleagues' participation and providing guidance in a predetermined course of action (Hautala, 2006). An effective leadership style, according to (Ahmad, 2018), influences change and provides impetus for transformation. Transformational leadership is a people-oriented leadership style that encourages subordinates to perform above and beyond their normal performance levels for the benefit of the organisation (Apridar \& Adamy, 2018). Emotional attachments form between the leader and the follower during this process (Castao, Li \& Li, 2018). Transformational leaders gain influence through relationship-building and are perceived to be trusting and supportive, according to (Rakowska \& de Juana-Espinosa, 2018). Transformational leaders strategically increase job satisfaction by instilling in their followers a clear mission, vision, and values (Paleczek, Bergner \& Rybnicek, 2018; Islam, et al., 2018). They have the ability to inspire and motivate followers to engage in extraordinary behaviours, thereby improving their performance levels (Vasconcelos, 2018). Without a doubt, the transformational leader must hone skills in order to effectively communicate the vision and pique the interests of followers. Transformational leadership, according to (Ali et al., 2020), consists of four components: idealised influence, inspirational motivation, intellectual stimulation, and individualised consideration.

\section{Idealized Influence}

It is followers' perception of the leader as a role model who is respected and confident while encouraging followers to reach their full potential (Bass, 1988). Effective and clear communication of vision and goals, according to (Akparobore \& Omosekejimi, 2020), results in acceptance and higher levels of satisfaction among followers. The leader instils high moral and ethical values in his or her followers in order to instil a sense of mission in them (Amah \& Oyetuunde, 2020). Followers tend to identify with the leader's moral and ethical values as a result of Idealised influence, earning them greater respect (Asad \& Nawab, 2020). According to one study, idealised influence creates an energising environment that reinforces empowerment, ownership, and responsibility among followers (Asad \& Nawab, 2020). Empowerment is viewed as a motivator in this context, which is explicitly supported by McClelland's theory of needs, in which the acquisition of power serves as a motivator to be more influential among peers (Braumandl, Diller, Muehlberger \& Jonas, 2020). Maslow's hierarchy of needs and Herzberg's two factor theory both support the need for responsibility and belonging (Braumandl et al., 2020). As a result, the current study hypothesises that H1: Idealised Influence has a significant positive effect on employee innovativeness and job satisfaction.

\section{Inspirational Motivation (IM)}

Transformational leadership occurs when a leader articulates goals and provides followers with a vision for how to achieve them (Bass, 1988). Subordinates who rated charismatic leaders positively described them as creative, open-minded, innovative, daring, committed, energised, team-oriented, accomplished, and empowering, while those who rated them negatively described them as overbearing, over-enthusiastic, innovative, ambitious, zealous, and arrogant. They discovered that $50 \%$ of respondents preferred relationship-oriented leaders, $30 \%$ preferred charismatic leaders, and 20\% preferred task-oriented leaders. Relationship-oriented leaders' subordinates valued unexpected extrinsic rewards, whereas charismatic leaders' subordinates valued participation (Alharbi, Javed, \& Malik, 2020). Transformational leaders can influence turnover intentions, for example, by inspiring 
subordinates and convincing them to commit to common goals, rather than by cultivating high-quality relationships (Jakubik, 2020). They accomplish this by ensuring that there is no conflict between the subordinate's personal goals and values and the team's or organization's goals and values (Lambert, 2020). Despite the fact that transformational leadership works both ways, the leader initiates and maintains the relationship and sets the tone for the exchange (Groelj, Grah, Penger \& erne, 2020). The leader must also recognise and consider the motives of subordinates in order to influence their future motives (Leiß \& Zehrer, 2020). As a result, the current study hypothesises:

$\mathrm{H} 2$ : There is a significant positive effect of inspirational motivation on employee innovativeness and job satisfaction.

\section{Intellectual Stimulation (IS)}

The transformational behaviour of a leader challenges followers to find new and innovative solutions to old and new problems (Bass, 1988). The Oldham and Hackman job characteristics model also supports the claim that internal motivation is gained through experienced meaningfulness from task variety and task significance (George \& Akinwale, 2020). According to (Nimran, Utami, Cahyana, \& Iqbal, 2020), followers at lower levels of the organisation may lack the autonomy to promote innovative processes. This is especially noticeable where tasks and responsibilities are more rigid. Rather than being seen as innovators, followers at lower levels frequently serve as enforcers of standards to protect the organization's identity (Robinson \& Fiset, 2020). It is also argued that because managers understand the nature of the job, they are able to frame tasks in challenging ways for followers, thereby creating a stimulating environment (Forner, Berry, Eidenfalk, \& Jones, 2020). According to the findings of a study conducted by (Björklund \& Larsson, 2020), job satisfaction is positively correlated with intellectual stimulation. As a result, the current study hypothesises that

H3: Intellectual stimulation has a significant positive effect on employee innovativeness and job satisfaction.

\section{Individual Consideration (IC)}

This is a method of assisting and developing followers' individual growth within the context of the organization's goals. According to (Alharbi et al., 2020), individualised consideration improves follower satisfaction by advising, supporting, and addressing individual needs. As a result, a stable platform is established, allowing followers to develop and self-actualize (Oswald A. J. Mascarenhas, 2019a). It is becoming increasingly important for leaders to use emotional intelligence when aligning followers' personal needs with those of the organisation (Ntayi, Munene, Nkurunziza \& Kaberuka, 2019). Furthermore, the process's ultimate goal is for the organisation to benefit from the transactional leadership process (Urbano et al., 2019). Furthermore, delegating authority to foster growth through personal challenges and experiences fosters a sense of ownership and responsibility among followers (Ludvik \& Nolan-Araez, 2018). Followers can thus be reminded on a regular basis that their specific needs are being met. The claims made above are supported by Oldham and Hackman's job characteristics model (psychological states) and Herzberg's two factor theory (motivators). As a result, the current study hypothesises that

H4: Individual consideration has a significant positive effect on employee innovativeness and job satisfaction.

\section{Employees' Innovativeness}


To understand how to lead creative and innovative individuals, one must first understand the type of process at hand, the type of people involved, and how a leader can influence both the process and the individuals (Janssen, Renkema \& Bos-Nehles, 2017). It has been discovered that when creativity is supported and promoted in an organisation, the number of innovations may increase, and even individuals "who lack the natural inclination to be creative may become creative," with leaders playing a critical role in enabling this (Pasamar, de la RosaNavarro, \& Diaz-Fernandez, 2019). (McLaughlin \& McLaughlin, 2020) concluded in their review that leaders and their subordinates can exercise their creativity most effectively in organisations that encourage innovation and are de-formalized and de-centralized. (Lien, Mutonyi \& Sltten, 2020) concluded that "supportive, inspirational, and non-controlling leadership" can improve employee creativity. Leaders can also assist innovators by communicating supportive values to subordinates and encouraging team members to engage in external communication with various stakeholders, which increases creativity (Groelj et al., 2020). As a result, the current study hypothesises that

H5: There is a significant mediating effect of employee innovativeness on job satisfaction via dimensions of transformational leadership.

On the basis of the preceding context, this study proposed five hypotheses and modelled the following structure (Figure 1).

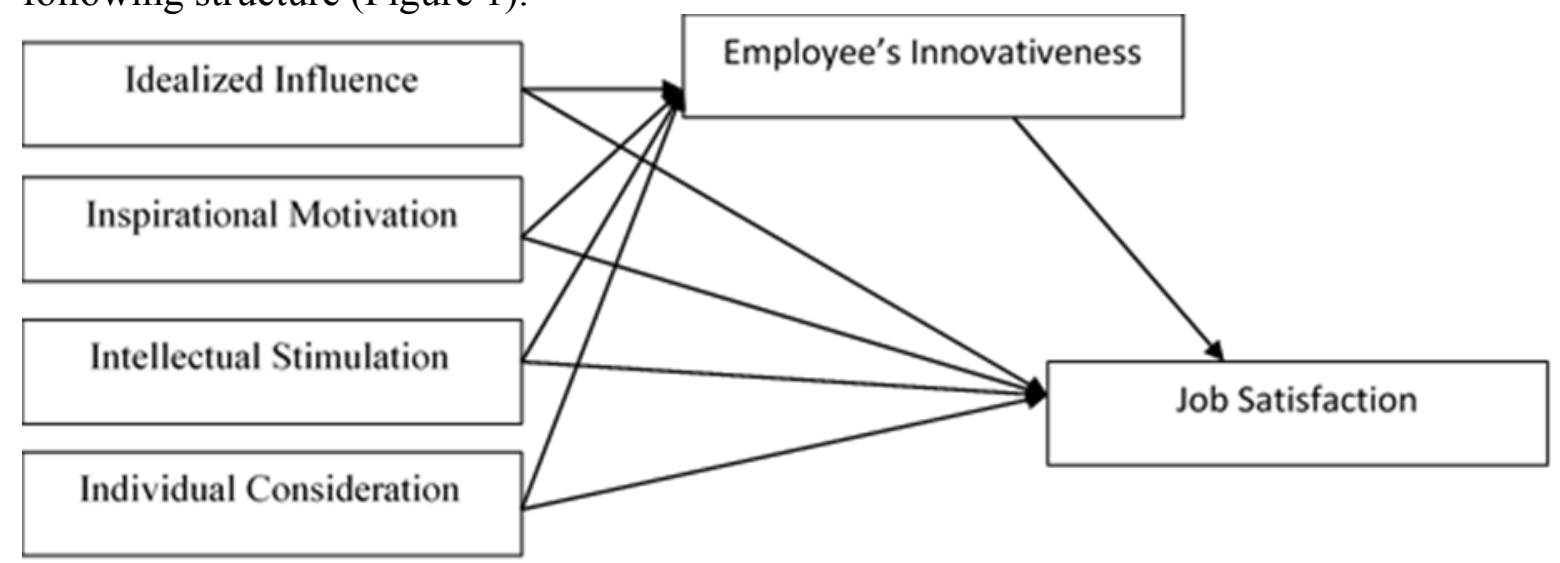

Figure 1: Conceptual Model

\section{Methods}

A standard rating questionnaire was developed and distributed to employees from the sampling population. In order to provide valuable insight into the study's objectives, questions were formulated based on a review of relevant literature. The questionnaires were used in a pilot test to detect possible measurement flaws, identify unclearly formulated items, and, most importantly, to observe nonverbal behaviours. Before conducting the research, the questionnaires were modified as needed. Face and content validity were used to determine validity. Reliability analysis was used to test each construct's internal consistency, ensuring a high degree of generalisation across items in the test. The research instrument had four sections: a letter of consent, a biographical information section, a job satisfaction and individual innovativeness questionnaire, and a leadership styles questionnaire. It was also mentioned that participation was entirely voluntary, and that respondents could opt out of the study at any time. In addition, a letter of consent was submitted to the organization's general manager, requesting permission to conduct the survey. 
Overall, job satisfaction was assessed using an adapted version of the Minnesota Satisfaction Questionnaire (MSQ) (alpha coefficient of 0.92), developed by Weiss, Darwiss, England, and Lofquist (1967) as supported by previous studies (Abugre, 2014; Bakotić, 2016), as well as items related to employee inventiveness (Buitendach \& Rothmann, 2009). The questionnaire had 20 questions, all of which were graded on a five-point Likert scale. The most recent version of the MLQ (form 5X-Short) (Bass \& Avolio, 2004) was used to assess teacher perceptions of department head leadership behaviour. The MLQ was scored on a scale of 1 to 7, with 1 representing Extremely Disagree and 7 representing Extremely Agree. The questionnaire contained pertinent information and issues that aided all participants. Closed-ended questions with Likert-type scales and multiple-choice questions were appropriate for the homogeneity portion of recording the demographics of the participants. A multiple-choice questionnaire included in the survey packets was used to collect demographic information. The participants were asked for their gender, age, education level, position title, and tenure at their prospective agencies, as well as how many federal agencies they had worked for. The raw data from the surveys was calculated using SPSS and structural equation modelling. The means, frequencies, standard deviation, and range were used to examine descriptive statistics for demographics (primary and predictor). In order to determine the impact of biographic variables on leadership styles and job satisfaction, inferential statistics like the T-Test and ANOVA were used. The relationship between leadership styles and job satisfaction was investigated using correlation analyses. The MLR of two or more dependent and independent variables was calculated using this software. This software was used for data analysis in the study, with a significance level of $p<0.05$.

This study's population consisted of employees from various private organisations located throughout Pakistan's metropolitan area. The study area employs approximately 33,000 people (Office of Personal Management, 2017). The sample for this study was drawn from a list of about 70 private organisations whose experiences could be used to answer the research questions. Participants were invited to participate in this study via e-mail, followed by a phone call if necessary. This study used probabilistic sampling with a simple random sampling method to select participants so that everyone in the population has an equal chance of being chosen, giving everyone the option to participate or opt out at their leisure (West, 2016). Because of the sensitive nature of the subject, all responses were treated as anonymous. All completed questionnaires were placed in sealed boxes strategically placed throughout the organisation. An independent research assistant was used to administer questionnaires and collect data. The research assistant was also briefed on the subject so that she could assist respondents who needed clarification on questions.

\section{Results and Discussion}

Questionnaires with missing data were no longer considered for further analysis, accounting for approximately $4 \%$ of total responses. 308 completed questionnaires were deemed suitable for further analysis, which is an adequate number of responses for this study. There were 161 male respondents and 147 female respondents. The two largest groups of participants have been employed for three years (18.2 percent) and four years (11 percent). The majority of participants are employed in the computer/IT and hotel industries (11.7 percent). All of the respondents in this study came from various levels of management. The majority of our respondents were senior directors or information system directors (33.1 percent). Idealized behaviour, inspirational motivation, intellectual stimulation, and individualised consideration had means of 4.752, 5.01, 4.62, and 4.81, with standard deviations of $1.329,1.185,1.369$, and 1.335 , respectively. The overall mean score for 
employee job satisfaction was $4.63(\mathrm{SD}=1.314)$, indicating a high mean for job satisfaction. A percentile score of 74 or higher indicates high satisfaction; a percentile score of 26-74 indicates moderate satisfaction; and a percentile score of 25 or lower indicates low satisfaction (D. J. Weiss et al., 1967). The mean level of employee innovativeness was 4.63 $(\mathrm{SD}=1.314)$, indicating that employees were generally satisfied with the services provided by their organisation.

According to (Bryman, 2008), factor analysis is "used in relation to multipleindicator measures to determine whether groups of indicators tend to bunch together to form distinct clusters known as factors." Exploratory factor analysis was used in this study to split the multiple item measurement on the Likert scale that reveals dimensions of transformational leadership affecting employee innovativeness and satisfaction in the Pakistan private sector. Construct score values were used in this study to determine the relationship between these leadership dimensions and the dependent factors of employee innovativeness and job satisfaction using Structural Equation Modelling (SEM).

\section{Table 1 Total Variance Explained}

\begin{tabular}{|c|c|c|c|c|c|c|c|c|c|}
\hline \multirow[t]{2}{*}{ Component } & \multicolumn{3}{|c|}{ Initial Eigenvalues } & \multicolumn{3}{|c|}{$\begin{array}{c}\text { Extraction Sums of Squared } \\
\text { Loadings }\end{array}$} & \multicolumn{3}{|c|}{$\begin{array}{c}\text { Rotation Sums of Squared } \\
\text { Loadings }\end{array}$} \\
\hline & Total & $\begin{array}{c}\% \text { of } \\
\text { Variance }\end{array}$ & $\begin{array}{c}\text { Cumulative } \\
\%\end{array}$ & Total & $\begin{array}{c}\% \text { of } \\
\text { Variance }\end{array}$ & $\begin{array}{c}\text { Cumulative } \\
\%\end{array}$ & Total & $\begin{array}{c}\% \text { of } \\
\text { Variance }\end{array}$ & $\begin{array}{c}\text { Cumulative } \\
\%\end{array}$ \\
\hline 1 & 7.614 & 47.577 & 47.577 & 7.614 & 47.577 & 47.577 & 3.575 & 22.328 & 22.328 \\
\hline 2 & 2.782 & 17.375 & 64.949 & 2.782 & 17.375 & 64.949 & 3.285 & 20.519 & 42.849 \\
\hline 3 & 1.385 & 8.646 & 73.595 & 1.385 & 8.646 & 73.595 & 3.108 & 19.417 & 62.264 \\
\hline 4 & 1.217 & 7.596 & 81.188 & 1.217 & 7.596 & 81.188 & 3.029 & 18.926 & 81.188 \\
\hline 5 & .528 & 3.289 & 84.476 & & & & & & \\
\hline 6 & .396 & 2.464 & 86.938 & & & & & & \\
\hline 7 & .369 & 2.296 & 89.232 & & & & & & \\
\hline 8 & .318 & 1.994 & 91.223 & & & & & & \\
\hline 9 & .254 & 1.575 & 92.796 & & & & & & \\
\hline 10 & .242 & 1.499 & 94.293 & & & & & & \\
\hline 11 & .207 & 1.275 & 95.566 & & & & & & \\
\hline 12 & .179 & 1.114 & 96.678 & & & & & & \\
\hline 13 & .169 & 1.048 & 97.723 & & & & & & \\
\hline 14 & .146 & .905 & 98.626 & & & & & & \\
\hline 15 & .127 & .784 & 99.408 & & & & & & \\
\hline 16 & .097 & .596 & 100.000 & & & & & & \\
\hline
\end{tabular}

This study compared data to the crucial assumption of structural equation modelling. According to the fitness indices, the data fit well with the survey data. Overall goodness-offit statistics were all within acceptable bounds. The Normed Chi-square was less than 5, and the RMSEA and RMR were less than 0.10 and 0.08 , respectively. The values of the normed fit index and other fit indices were well above the desired level, indicating support for the conceptual model. As a result, these findings indicate that the conceptual model was well and adequately fit, providing confidence to test the proposed hypothesis.

Table 2 displays the hypothesis testing results, including beta value, significant value, and critical value. Except for one, the results showed that all hypotheses were significantly supported. Because the significant value was greater than 0.05 , the relationship between individual consideration and job satisfaction was insignificant. Unsurprisingly, all significant factors have a positive impact on both employee innovativeness and job satisfaction. 
Table 2 Path coefficient for the Final Model for hypothesis testing

\begin{tabular}{|c|c|c|c|c|}
\hline Variable & Variable & $\begin{array}{l}\text { Path } \\
\text { Coefficients }\end{array}$ & Sig. & Critical Ratio \\
\hline $\begin{array}{l}\text { Idealized } \\
\text { Influence }\end{array}$ & $\begin{array}{l}\longleftarrow \text { Employee } \\
\text { innovativeness }\end{array}$ & .410 & 0.000 & 12.013 \\
\hline $\begin{array}{l}\text { Idealized } \\
\text { Influence }\end{array}$ & $\longleftarrow$ Job Satisfaction & .426 & 0.000 & 8.137 \\
\hline $\begin{array}{l}\text { Inspirational } \\
\text { Motivation }\end{array}$ & $\longleftarrow \begin{array}{l}\text { Employee } \\
\text { innovativeness }\end{array}$ & .262 & 0.000 & 5.791 \\
\hline $\begin{array}{l}\text { Inspirational } \\
\text { Motivation }\end{array}$ & $\longleftarrow$ Job Satisfaction & .265 & 0.000 & 4.778 \\
\hline $\begin{array}{l}\text { Intellectual } \\
\text { Stimulation }\end{array}$ & $\longleftarrow \begin{array}{l}\text { Employee } \\
\text { innovativeness }\end{array}$ & .103 & 0.000 & 3.735 \\
\hline $\begin{array}{l}\text { Intellectual } \\
\text { Stimulation }\end{array}$ & $\longleftarrow$ Job Satisfaction & .092 & 0.004 & 2.865 \\
\hline $\begin{array}{l}\text { Individual } \\
\text { Consideration }\end{array}$ & $\begin{array}{l}\longleftarrow \text { Employee } \\
\text { innovativeness }\end{array}$ & .056 & 0.048 & 1.967 \\
\hline $\begin{array}{l}\text { Individual } \\
\text { Consideration }\end{array}$ & $\longleftarrow$ Job Satisfaction & .022 & .551 & .586 \\
\hline $\begin{array}{l}\text { Employee } \\
\text { innovativeness }\end{array}$ & $\longleftarrow$ Job Satisfaction & .416 & .000 & 4.644 \\
\hline
\end{tabular}

This study also examined the mediating effect of employee innovativeness on job satisfaction in Pakistan's private sector via transformational leadership. This study presents direct, indirect, and total effects to measure the mediating effect. Table 3 displays the results. Based on the findings, it is clear that transformational leadership has a significant mediating effect on employees' innovativeness and job satisfaction. As a result, hypothesis 5 is accepted.

Table 3 Mediation Analysis

\begin{tabular}{|l|l|l|l|l|l|l|}
\hline & IC & IS & IM & II & EI & JS \\
\hline \multicolumn{7}{|l|}{ Direct Effects } \\
\hline EI & .056 & .103 & .262 & .410 & .000 & .000 \\
\hline JS & .020 & .071 & .060 & .428 & .435 & .000 \\
\hline \multicolumn{7}{|l|}{ Indirect Effects } \\
\hline EI & .000 & .000 & .000 & .000 & .000 & .000 \\
\hline JS & .024 & .043 & .110 & .171 & .000 & .000 \\
\hline \multicolumn{7}{|l|}{ Total Effects } \\
\hline EI & .056 & .103 & .262 & .410 & .000 & .000 \\
\hline JS & .044 & .114 & .169 & .599 & .435 & .000 \\
\hline
\end{tabular}




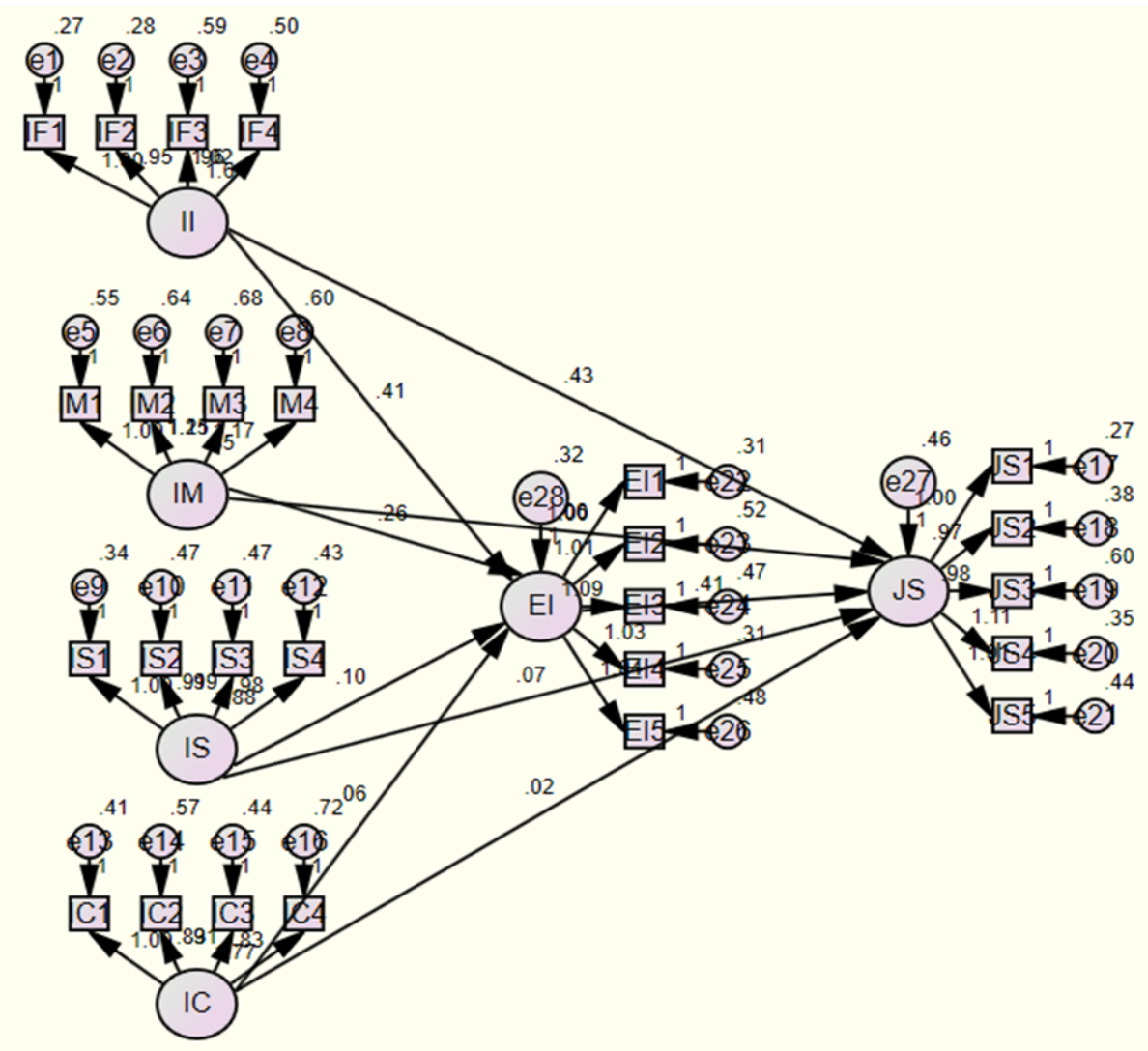

Figure 2: Final Model

Participants in Pakistan's private sector responded positively to an overall mean score of 4.725 for idealised influence on the MLQ, indicating that their leaders routinely exhibited idealised influence. According to the MLQ's norm tables, this score indicated that employees perceived their leaders as more transformational than nearly 42 percent of leaders worldwide in idealised influence. Furthermore, the relationship between idealised influence and job satisfaction yielded a beta of.428. The relationship was strongly positive, indicating that employees in the private sector who work with leaders who exhibit high levels of idealised influence in their transformational leadership behaviour tend to be more satisfied with their jobs. This finding was consistent with the findings of (Chon \& Lee, 2020), who concluded that there was a positive and significant relationship between transformational leadership and job satisfaction.

The study's findings show a link between inspirational motivation of transformational leadership and job satisfaction. Participants in the Pakistan private sector responded positively with an overall mean score of 5.01 for inspirational motivation on the MLQ, indicating that their leaders routinely demonstrated inspirational motivation. In terms of inspirational motivation, this score indicated that employees perceived their leader as more transformational than 42 percent of leaders worldwide. Furthermore, the correlation between inspirational motivation and job satisfaction was found to be $r=.261$. The relationship was strongly positive, indicating that employees in the private sector who work with leaders who exhibit high levels of inspirational motivation and transformational leadership behaviour have a higher level of job satisfaction. This finding was consistent with the findings of (Asad \& Nawab, 2020), who concluded that there was a positive and significant relationship between transformational leadership and job satisfaction. 
Participants in Pakistan's private sector responded positively with an overall mean of 4.62 for intellectual stimulation on the MLQ, indicating that their leaders routinely demonstrated intellectual stimulation. In terms of intellectual stimulation, the score indicated that employees perceived their leaders as more transformational than approximately 45 percent of leaders worldwide. Furthermore, the correlation between intellectual stimulation and job satisfaction was found to be $r=.094$. The relationship was strongly positive, indicating that employees in the private sector who work with leaders who exhibit high levels of intellectual stimulation and transformational leadership behaviour have a higher level of job satisfaction. This finding was consistent with the findings of (Manoppo, 2020), who concluded that there was a positive and significant relationship between transformational leadership and job satisfaction.

The findings revealed that participants in Pakistan's private sector reported their leaders routinely exhibited individualised consideration, with an overall mean score of 4.81 on the MLQ for individualised consideration. In individualised consideration, this score indicated that employees perceived their leaders as less transformational than nearly $70 \%$ of leaders worldwide. The correlation between individualised consideration and job satisfaction was $\mathrm{r}=.020$, which was not statistically significant. The relationship was not statistically significant, implying that employees in the private sector who work with leaders who demonstrate high levels of individualised consideration of transformational leadership behaviour do not have a higher level of job satisfaction. This finding was consistent with the findings of (Modha, 2020), who concluded that there was a positive and significant relationship between transformational leadership and job satisfaction.

\section{Implications of the Study}

This study shows that the transformational leadership-innovativeness nexus in private organisations adjusts to situations based on a specific environmental factor, namely varying levels of external new knowledge acquisition by team members. At one end of the spectrum, the results of this study show that transformational leadership has a direct influence on team innovativeness in teams with lower levels of knowledge acquisition opportunities from external sources. On the other end of the spectrum, in teams with higher levels of external knowledge acquisition opportunities, the indirect influence of transformational leadership on team innovativeness is prevalent, mediated through team reflexivity. The findings of this study can be used by leaders in both the public and private sectors to gain an understanding of transformational leadership philosophy and job satisfaction in implementing good qualifications and leadership preparation. The private sector is the country's foundation, and the country's economy works tirelessly on behalf of the government and the people. Job success, job satisfaction, and motivation are important factors, and leaders who understand and accept their leadership styles should integrate their skills into a regular framework of performance and education.

\section{Limitations of the Study}

The study was limited in that the results of participant responses were not analysed or compared based on race differences. Another difference was that workers who responded outside of the workplace were not asked to state their heritage or nationality in order to determine whether culture plays a role in the effect of transformational leadership on employee satisfaction and innovation. A leader cannot develop motivational strategies to improve employee efficiency unless they are aware of this (e.g., incentive and recognition). The MLQ is one of the most widely used methods for assessing organisational leadership 
capacities, but its validity has long been questioned. According to research, the importance of different leadership styles varies across cultures, which complicates the use of the MLQ as a method of evaluating leadership. Finally, time, money, and the commitment of employees outside of the workplace are all limitations of this report.

\section{Recommendations for Future Research}

Similar studies can be conducted to compare private and public universities and see how their transformation methods affect their followers' job satisfaction and understanding of innovation. Individual consideration and job satisfaction may differ according to age group. Researchers will also need to discuss why the age ranges for these two groups differ. Furthermore, because this study was solely quantitative, employing questionnaires and statistical data, future studies could take a more experimental approach, employing focus groups and observations to add qualitative steps, allowing for more insightful inputs. The study also focused on overall job satisfaction and worker innovation without taking their measurements into account. In the research model, their dimensions (intrinsic and external) and innovativeness (tangibility, reliability, responsiveness, assurance, and empathy) were not evaluated on a case-by-case basis. As a result, it is suggested that future research include the sub-constructs of work satisfaction and innovativeness to determine the potential relationship between these sub-constructs and study variables.

\section{Conclusion}

According to the findings of this study, if private company leaders adopt transformational leadership behaviours, their employees will be happier and more committed. The study's practical contribution includes significant theoretical contributions to the literature on transformational leadership, work satisfaction, and employee creativity. The findings of this study should aid in better understanding of the conditions that promote transition leadership behaviour in terms of employee satisfaction and employee innovation. This study also explains how perceptions of transformational leadership can lead to positive outcomes for public organisations. This result was significant because it demonstrated that transformational leadership was an important factor in improving job satisfaction and innovation for private-sector workers. Researchers discovered a link between transformational leadership and a willingness to work hard (Bass, 1998). Working with a leader who used a transformational leadership style would inspire followers to strive even harder to excel and achieve their organisations' goals. Furthermore, the results of this study appear to confirm Bass' (1985) model, which states that transformational leadership is projective for both individual and group success and engagement. The findings of this study will enable private sector leaders in general, and Pakistan's private organisations in particular, to plan and manage strategies that will lead them to achieve and exceed their organisational goals. 


\section{References}

Abdullahi, A. Z., Anyigba, H., \& Anarfo, E. B. (2020). The impact of leadership style on organizational citizenship behavior: does leaders' emotional intelligence play a moderating role? Journal of Management Development, 39(9/10), 963-987. doi:10.1108/JMD-01-2020-0012

Abugre, J. B. (2014). Job Satisfaction of Public Sector Employees in Sub-Saharan Africa: Testing the Minnesota Satisfaction Questionnaire in Ghana. International Journal of Public Administration, 37(10), 655-665. doi:10.1080/01900692.2014.903268

Ahmad, A. (2018). The relationship among job characteristics organizational commitment and employee turnover intentions. Journal of Work-Applied Management, 10(1), 7492. doi:10.1108/JWAM-09-2017-0027

Akparobore, D., \& Omosekejimi, A. F. (2020). Leadership qualities and style: a panacea for job productivity and effective service delivery among library staff in academic libraries in South South, Nigeria. Library Management, 41(8/9), 677-687. doi:10.1108/LM-02-2020-0025

Al-Awlaqi, M. A., Battour, M., Barahma, M. M., \& Aamer, A. M. (2021). The interaction between leadership styles and their followers' human capital: a correspondence analysis approach applied to micro-sized businesses. Journal of Management Development, 40(1), 74-93. doi:10.1108/JMD-05-2019-0172

Al-Ghazali, B. M. (2020). Transformational leadership, career adaptability, job embeddedness and perceived career success: a serial mediation model. Leadership \& Organization Development Journal, 41(8), 993-1013. doi:10.1108/LODJ-102019-0455

Alenezi, A. (2020). The regional challenges affecting Pakistan's national security. Review of Economics and Political Science, 5(1), 57-68. doi:10.1108/REPS-06-2019-0088

Alharbi, M. M. H., Javed, S., \& Malik, A. (2020). The relevance of leadership styles and Islamic work ethics in managerial effectiveness. PSU Research Review, 4(3), 189207. doi:10.1108/PRR-03-2019-0007

Ali, M., Imran, M., Almansoori, R. G., Zeb, A., \& Rehman, F. u. (2020). Authentic leadership traits, high-performance human resource practices and job performance in Pakistan. International Journal of Public Leadership, 16(3), 299-317. doi:10.1108/IJPL-02-2020-0011

Almeida Jones, A., Knight, E., Mitchell, V.-W., \& Harvey, W. S. (2021). The tensions of defining and developing thought leadership within knowledge-intensive firms. Journal of Knowledge Management, ahead-of-print(ahead-of-print). doi:10.1108/JKM-06-2020-0431

Amah, O. E., \& Oyetuunde, K. (2020). The effect of servant leadership on employee turnover in SMEs in Nigeria: the role of career growth potential and employee voice. Journal of Small Business and Enterprise Development, 27(6), 885-904. doi:10.1108/JSBED-01-2019-0009

Anadol, Y., \& Behery, M. (2020). Humanistic leadership in the UAE context. Cross Cultural \& Strategic Management, 27(4), 645-664. doi:10.1108/CCSM-01-2020-0023

Apridar, \& Adamy, M. (2018). The Effect of Job Satisfaction and Work Motivation on Organizational Commitment and Organizational Citizenship Behavior in BNI in the Working Area of Bank Indonesia Lhokseumawe Proceedings of MICoMS 2017 (Vol. 1, pp. 1-5): Emerald Publishing Limited.

Asad, M. M., \& Nawab, A. (2020). Leadership practices of school principal through a distributed leadership lens: a case study of a secondary school in urban Pakistan. 
International Journal of Public Leadership, 16(4), 411-422. doi:10.1108/IJPL-082020-0081

Bahadori, M., Hosseini, S. M., Alimohammadzadeh, K., Hasanpoor, E., \& Ghasemi, M. (2021). The influence of ethical leadership on the organizational commitment in fire organizations. International Journal of Ethics and Systems, 37(1), 145-156. doi:10.1108/IJOES-04-2020-0043

Bakotić, D. (2016). Relationship between job satisfaction and organisational performance. Economic Research-Ekonomska Istraživanja, 29(1), 118-130. doi:10.1080/1331677X.2016.1163946

Björklund, C., \& Larsson, G. (2020). Age and leadership: comparisons of age groups in different kinds of work environment. Management Research Review, ahead-of$\operatorname{print}$ (ahead-of-print). doi:10.1108/MRR-01-2020-0040

Braumandl, I., Diller, S. J., Muehlberger, C., \& Jonas, E. (2020). Supporting students with coaching or training depending on their basic psychological needs. International Journal of Mentoring and Coaching in Education, ahead-of-print(ahead-of-print). doi:10.1108/IJMCE-08-2020-0050

Bryman, A. (2008). Of methods and methodology. Qualitative Research in Organizations and Management: An International Journal, 3, 159-168. doi:10.1108/17465640810900568

Buitendach, J., \& Rothmann, S. (2009). The validation of the Minnesota Job Satisfaction Questionnaire in selected organisations in South Africa. South African Journal of Human Resource Management, 7. doi:10.4102/sajhrm.v7i1.183

Castaño, G., Li, Y., \& Li, Y. (2018). Linking leadership styles to work engagement. Chinese Management Studies, 12(2), 433-452. doi:10.1108/CMS-04-2017-0108

Chen, Z., Zhang, J., Yang, J., Chang, M., \& Zhou, L. (2020). The chain mediation effect of spiritual leadership on employees' innovative behavior. Leadership \& Organization Development Journal, 42(1), 114-129. doi:10.1108/LODJ-10-2019-0442

Chon, M.-G., \& Lee, Y. (2020). Transformational leadership and employee communication behaviors: the role of communal and exchange relationship norms. Leadership \& Organization Development Journal, 42(1), 61-82. doi:10.1108/LODJ-02-2020-0060

Forner, V. W., Berry, Y., Eidenfalk, J., \& Jones, M. (2020). Motivating workers: how leaders apply self-determination theory in organizations. Organization Management Journal, ahead-of-print(ahead-of-print). doi:10.1108/OMJ-03-2020-0891

George, O. J., \& Akinwale, O. E. (2020). Work environment and job satisfaction among nurses in government tertiary hospitals in Nigeria. Rajagiri Management Journal, 14(1), 71-92. doi:10.1108/RAMJ-01-2020-0002

Ghiasipour, M., Mosadeghrad, A. M., Shaqura, I. I., \& Jaafaripooyan, E. (2020). A leadership model for Iranian health-care organizations. Leadership in Health Services, 33(4), 461-475. doi:10.1108/LHS-05-2020-0022

Grošelj, M., Grah, B., Penger, S., \& Černe, M. (2020). Authentic and transformational leadership and innovative work behaviour: the moderating role of psychological empowerment. European Journal of Innovation Management, ahead-of-print(aheadof-print). doi:10.1108/EJIM-10-2019-0294

Hautala, T. M. (2006). The relationship between personality and transformational leadership. Journal of Management Development, 25(8), 777-794. doi:10.1108/02621710610684259

Hsu, H.-H., Hsieh, H.-H., Wang, C.-C., \& Kao, K.-Y. (2020). Ethical leadership and employee unethical pro-organizational behavior: a moderated mediation model of 
moral disengagement and coworker ethical behavior. Leadership \& Organization Development Journal, 41(6), 799-812. doi:10.1108/LODJ-10-2019-0464

Islam, M. A., Jantan, A. H., Rahman, M. A., Hamid, A. B. A., Mahmud, F. B., \& Hoque, A. (2018). Leadership Styles for Employee Empowerment: Malaysian Retail Industry. Journal of Management Research, 10(4), 27-40.

Jakubik, M. (2020). How can practical wisdom manifest itself in five fundamental management and leadership practices? Vilakshan - XIMB Journal of Management, ahead-of-print(ahead-of-print). doi:10.1108/XJM-08-2020-0078

Janssen, M., Renkema, M., \& Bos-Nehles, A. (2017). HRM and innovative work behaviour: a systematic literature review. Personnel Review, 46(7), 1228-1253. doi:10.1108/PR09-2016-0257

Kanthong, S. N., Khummueng, K., \& Na-Nan, K. (2020). Development of an empowering leadership scale for salespeople: validation and reliability. Industrial and Commercial Training, 52(3), 209-220. doi:10.1108/ICT-02-2020-0025

Khan, A. M., Jantan, A. H. B., Salleh, L. B. M., Dato'Mansor, Z., Islam, M. A., \& Hosen, S. (2019). The impact of transformational leadership effects on innovative work behavior by the moderating role of psychological empowerment. Journal of Reviews on Global Economics, 8, 925-938.

Kundu, S. C., Kumar, S., \& Lata, K. (2019). Effects of perceived role clarity on innovative work behavior: a multiple mediation model. RAUSP Management Journal, 55(4), 457-472. doi:10.1108/RAUSP-04-2019-0056

Lambert, S. (2020). Emotional awareness amongst middle leadership. Journal of WorkApplied Management, 12(2), 233-243. doi:10.1108/JWAM-02-2020-0009

Le, A. N.-H., \& Nguyen, T. H. (2019). Promoting creativity and innovation: expected and unexpected consequences. Asia Pacific Journal of Innovation and Entrepreneurship, 13(3), 296-310. doi:10.1108/APJIE-03-2019-0008

Leiß, G., \& Zehrer, A. (2020). Intergenerational communication barriers and pitfalls of business families in transition - a qualitative action research approach. Corporate Communications: An International Journal, 25(3), 515-532. doi:10.1108/CCIJ-032020-0056

Liang, L., Ma, C., Zhang, X., Tian, Y., Li, Z., \& Tian, G. (2020). "Too much of a good thing?": exploring the dark side of empowering leadership by linking it with unethical pro-organizational behavior. Leadership \& Organization Development Journal, 42(1), 32-46. doi:10.1108/LODJ-02-2020-0033

Lien, G., Mutonyi, B. R., \& Slåtten, T. (2020). Empowering leadership, work group cohesiveness, individual learning orientation and individual innovative behaviour in the public sector: empirical evidence from Norway. International Journal of Public Leadership, 16(2), 175-197. doi:10.1108/IJPL-07-2019-0045

Ludvik, M. B., \& Nolan-Arañez, S. I. (2018). Positing a framework for cultivating spirituality through public university leadership development. Journal of Research in Innovative Teaching \& Learning, 11(1), 94-109. doi:10.1108/JRIT-08-2017-0018

Luo, J., Guo, L., \& Cheng, K. (2020). The effect of exploitative leadership on knowledge hiding: a conservation of resources perspective. Leadership \& Organization Development Journal, 42(1), 83-98. doi:10.1108/LODJ-03-2020-0085

Manoppo, V. P. (2020). Transformational leadership as a factor that decreases turnover intention: a mediation of work stress and organizational citizenship behavior. The TQM Journal, 32(6), 1395-1412. doi:10.1108/TQM-05-2020-0097 
McLaughlin, J. F., \& McLaughlin, L. (2020). Do we innovate as we believe we do? Journal of Research in Innovative Teaching \& Learning, ahead-of-print(ahead-of-print). doi:10.1108/JRIT-10-2019-0073

Modha, B. (2020). Leadership and management culture within dental practice: a case study. Leadership in Health Services, 33(4), 417-428. doi:10.1108/LHS-04-2020-0018

Mohamed, E. A. (2019). The impact of political reform on the stability of the state of Kuwait since 2010. Journal of Humanities and Applied Social Sciences, 2(2), 101-114. doi:10.1108/JHASS-06-2019-0001

Muhammed, S., \& Zaim, H. (2020). Peer knowledge sharing and organizational performance: the role of leadership support and knowledge management success. Journal of Knowledge Management, 24(10), 2455-2489. doi:10.1108/JKM-03-20200227

Neve, H. H., Kæseler, S. M., Wandahl, S., \& Jensen, S. R. (2019). Towards Developing a Framework for User-Driven Innovation in Refurbishment. In I. Lill \& E. Witt (Eds.), 10th Nordic Conference on Construction Economics and Organization (Vol. 2, pp. 427-435): Emerald Publishing Limited.

Nimran, U., Utami, H. N., Cahyana, B. E., \& Iqbal, M. (2020). Organizational transformation as a determinant of corporate hospitality and its effect on corporate sustainability. International Trade, Politics and Development, 4(2), 105-125. doi:10.1108/ITPD-04-2020-0014

Ntayi, J., Munene, J., Nkurunziza, G., \& Kaberuka, W. (2019). Business process reengineering in developing economies. Innovation \& Management Review, 16(2), 118-142. doi:10.1108/INMR-03-2018-0010

Ohiani, A. S., \& Adeosun, O. T. (2020). Attracting and recruiting quality talent: firm perspectives. Rajagiri Management Journal, 14(2), 107-120. doi:10.1108/RAMJ05-2020-0016

Oswald A. J. Mascarenhas, S. J. (2019a). The Ethics of Corporate Ethical and Moral Charismatic Leadership Corporate Ethics for Turbulent Markets (pp. 113-149): Emerald Publishing Limited.

Oswald A. J. Mascarenhas, S. J. (2019b). References Corporate Ethics for Turbulent Markets (pp. 295-314): Emerald Publishing Limited.

Paleczek, D., Bergner, S., \& Rybnicek, R. (2018). Predicting career success: is the dark side of personality worth considering? Journal of Managerial Psychology, 33(6), 437456. doi:10.1108/JMP-11-2017-0402

Pasamar, S., de la Rosa-Navarro, M. D., \& Diaz-Fernandez, M. (2019). Human capital: the link between leadership and organizational learning. European Journal of Management and Business Economics, 28(1), 25-51. doi:10.1108/EJMBE-08-20170003

Portela Maquieira, S., Tarí, J. J., \& Molina-Azorín, J. F. (2020). Transformational leadership and the European Foundation for Quality Management model in five-star hotels. Journal of Tourism Analysis: Revista de Análisis Turístico, 27(2), 99-118. doi:10.1108/JTA-02-2019-0007

Quartey, S. H., Dartey-Baah, K., \& Adotey, A. (2020). Examining transformational and transactional leadership styles and safety citizenship behaviors in the power distribution sector: evidence from Ghana. International Journal of Energy Sector Management, 15(1), 173-194. doi:10.1108/IJESM-07-2020-0008

Rakowska, A., \& de Juana-Espinosa, S. (2018). Public sector motivational practices and their effect on job satisfaction: country differences. European Journal of 
Management and Business Economics, 27(2), 141-154. doi:10.1108/EJMBE-022018-0027

Robinson, M. A., \& Fiset, J. (2020). Developing foresight through the evaluation and construction of vision statements: an experiential exercise. Organization Management Journal, 17(2), 99-115. doi:10.1108/OMJ-03-2019-0822

Sarwar, A., Zahid, U., Imran, M. K., \& Anjum, Z.-U.-Z. (2020). How innovative climate leads to project success: the moderating role of gender and work culture. Innovation \& Management Review, 17(4), 413-430. doi:10.1108/INMR-08-2019-0096

Scicluna, A., \& Sammut, R. (2020). Nurses' and nurse managers' perceived transformational leadership behavioural practices: a survey. Leadership in Health Services, 33(4), 385-396. doi:10.1108/LHS-01-2020-0002

Singh, S., Srivastava, S., \& Singh, S. K. (2020). Relational exploration of the effect of workrelated scheme on job satisfaction. Vilakshan - XIMB Journal of Management, 17(1/2), 111-128. doi:10.1108/XJM-07-2020-0019

Skelton, A. R., Dwyer, R. J., \& Nattress, D. (2019). Predicting manufacturing employee turnover intentions. Journal of Economics, Finance and Administrative Science, 25(49), 101-117. doi:10.1108/JEFAS-07-2018-0069

Sorour, M. K., El-Sakhawy, A. A., Soobaroyen, T., \& Shrives, P. J. (2020). Exploring the evolving motives underlying corporate social responsibility (CSR) disclosures in developing countries: the case of "political CSR" reporting. Accounting, Auditing \& Accountability Journal, ahead-of-print(ahead-of-print). doi:10.1108/AAAJ-072019-4080

Strömberg, A., \& Vidman, Å. (2020). Leadership for a healthy work environment - a question about who, what and how. Leadership in Health Services, ahead-ofprint(ahead-of-print). doi:10.1108/LHS-06-2020-0041

Taufer, E., Severo, E. A., Perin, M. M. S., \& De Guimarães, J. C. F. (2020). The relationship between sustainable innovation and product or service innovation: a survey in companies in Rio Grande do Sul. Revista de Gestão, 27(4), 319-334. doi:10.1108/REGE-05-2019-0058

Urbano, D., Aparicio, S., \& Felix, C. (2019). Leadership as a driver of entrepreneurship: an international exploratory study. Journal of Small Business and Enterprise Development, 26(3), 397-420. doi:10.1108/JSBED-03-2018-0106

Vandavasi, R. K. K., Yepuru, P., Uen, J.-F., \& McConville, D. C. (2020). Knowledge sharing, shared leadership and innovative behaviour: a cross-level analysis. International Journal of Manpower, 41(8), 1221-1233. doi:10.1108/IJM-04-20190180

Vasconcelos, A. F. (2018). Older workers as a source of wisdom capital: broadening perspectives. Revista de Gestão, 25(1), 102-118. doi:10.1108/REGE-11-2017-002

Wallo, A., Ellström, P.-E., Elg, M., Kock, H., \& Berglund, M. (2020). Interactive research: concepts, contributions and challenges. Journal of Manufacturing Technology Management, 31(8), 1517-1537. doi:10.1108/JMTM-09-2018-0304

Wang, J., Morrison, A. M., Xie, C., Zhang, J., \& Coca-Stefaniak, J. A. (2020). Responding to a major global crisis: the effects of hotel safety leadership on employee safety behavior during COVID-19. International Journal of Contemporary Hospitality Management, 32(11), 3365-3389. doi:10.1108/IJCHM-04-2020-0335

West, P. W. (2016). Simple random sampling of individual items in the absence of a sampling frame that lists the individuals. New Zealand Journal of Forestry Science, 46(1), 15. doi:10.1186/s40490-016-0071-1. 
Wilson, D. E. (2020). Moving toward democratic-transformational leadership in academic libraries. Library Management, 41(8/9), 731-744. doi:10.1108/LM-03-2020-0044

Zhang, H., \& Kang, F. (2020). Ethical leadership and newcomer adjustment: examining a moderated mediation model. Leadership \& Organization Development Journal, 41(8), 1053-1068. doi:10.1108/LODJ-10-2019-0427 